\title{
PENGEMBANGAN MEDIA EDUKASI GIZI BERBASIS ANDROID DAN WEBSITE SERTA PENGARUHNYA TERHADAP PERILAKU TENTANG GIZI SEIMBANG SISWA SEKOLAH DASAR
}

\section{(The development of nutrition education media based on android and website and the effects on behavior about balanced nutrition in primary school students)}

\author{
Fachruddin Perdana $^{1 *}$, Siti Madanijah ${ }^{1}$, Ikeu Ekayanti ${ }^{1}$ \\ ${ }^{1}$ Departemen Gizi Masyarakat, Fakultas Ekologi Manusia (FEMA), Institut Pertanian Bogor, Bogor 16680
}

\begin{abstract}
The objective of this study were to analyze the effect of nutrition education media based on android and website to behavior and their relationships with balanced nutrition in primary school students. The design of this study was quasy experimental. A pre-post intervention study was conducted in Tuban City, East Java-Indonesia and involved 144 grades 5 primary school students. The intervention was conducted at the school by applying nutrition education media such as poster, powerpoint presentation, android, and website. A self-administered measurement with a validated questionnaire was applied to assess balanced nutrition behavior before and after the program. The result showed that a total of $72.9 \%$ school children had good knowledge, $78.5 \%$ positive attitude, $54.9 \%$ good practices on balanced nutrition before intervention. After the education program, the good knowledge, the positive attitude, and the good practices on balanced nutrition increased by $11.8 \%, 5.5 \%$, and $15.9 \%$, respectively. The media of nutrition education based on android was better than the others. In conclusion, the balanced nutrition behavior could be improved by the nutrition education program.
\end{abstract}

Keywords: android, balanced nutrition, nutrition education, school children, website

\begin{abstract}
ABSTRAK
Tujuan dari penelitian ini adalah menganalisis pengaruh media edukasi gizi berbasis android dan website terhadap perilaku serta hubungannya dengan gizi seimbang pada siswa sekolah dasar. Desain menggunakan quasy experimental dengan pre-post intervention study yang dilakukan terhadap 144 anak SD kelas 5 di Tuban, Jawa Timur. Intervensi dilakukan di sekolah dengan menggunakan media edukasi gizi seperti poster, powerpoint presentation, android, dan website. Perubahan perilaku gizi seimbang anak SD sebelum dan setelah intervensi diukur menggunakan kuesioner yang telah divalidasi. Sebelum intervensi terdapat $72,9 \%$ anak dengan tingkat pengetahuan baik, $78,5 \%$ anak dengan sikap positif, $54,9 \%$ anak dengan praktik gizi seimbang baik. Setelah intervensi, pengetahuan baik, sikap positif, dan praktik gizi seimbang yang baik meningkat masing-masing sebesar $11,8 \%, 5,5 \%$, dan $15,9 \%$. Media edukasi gizi berbasis android lebih baik dari media lainnya. Intervensi edukasi gizi meningkatkan perilaku gizi seimbang menjadi lebih baik.
\end{abstract}

Kata kunci: anak sekolah, android, edukasi gizi, gizi seimbang, website

\section{PENDAHULUAN}

Sumber daya manusia yang berkualitas akan membentuk generasi yang sehat dan cerdas baik secara emosi, intelegensia, ataupun spiritualnya serta tercermin dari status gizi optimal yang dicapai melalui konsumsi pangan beragam, bergizi, dan berimbang (Health \& Panaretto 2005). Pemerintah Indonesia telah menerapkan kebijakan untuk meningkatkan kualitas sumber daya manusia yaitu upaya perbaikan gizi masyarakat melalui penerapan gizi seimbang dalam

\footnotetext{
"Korespondensi: Telp: +6281380601948, Surel: fachruddin.perdana@gmail.com
} 
Peraturan Menteri Kesehatan Republik Indonesia (Permenkes RI) Nomor 41 Tahun 2014 tentang Pedoman Gizi Seimbang. Anak sekolah dasar (SD) belum seluruhnya mendapatkan dampak dari kebijakan itu, dikarenakan penerapannya belum optimal dan terdapat berbagai masalah pada perilaku makan, perilaku hidup bersih dan sehat, serta penyakit yang berkaitan dengan gizi sehingga diperlukan penyelenggaraan gizi seimbang berupa sosialisasi, penyuluhan, pelatihan, konseling, praktik gizi seimbang, dan edukasi gizi.

Edukasi gizi merupakan suatu metode serta upaya untuk meningkatkan pengetahuan gizi dan perilaku makan sehingga terciptanya status gizi optimal (Brun 1985; Ho et al. 2012). Edukasi gizi sangat penting diperlukan untuk anak $\mathrm{SD}$, dan bermanfaat bagi peningkatan perilaku gizi seimbang. Berbagai hasil penelitian menunjukkan bahwa intervensi edukasi gizi dapat meningkatkan perilaku anak SD dengan efektivitas yang berbeda-beda (Briawan 2016; Kocken et al. 2013; Nuryanto et al. 2014; Shariff et al. 2008; Shen et al. 2015; Wells et al. 2015).

Banyak tantangan dalam penyampaian pesan-pesan gizi pada anak SD. Anak SD merupakan kelompok yang mudah menerima program edukasi gizi (Rosario et al. 2013), akan tetapi mereka memiliki karakteristik tersendiri dalam pemilihan media untuk proses belajar karena hasrat yang besar untuk ingin tahu dan mempelajari lebih jauh (Suhardjo 2003). Ketidaktahuan timbul karena pengetahuan yang diberikan tidak teraplikasi dengan baik dan media penyampaiannya kurang tepat. Sehingga, edukasi gizi pada anak SD memerlukan adanya media yang edukatif, kreatif, dan inovatif (Bergmann et al. 2010).

Edukasi gizi berbasis edutaintment bermanfaat dalam meningkatkan pengalaman belajar secara menyeluruh bagi siswa (Singhal et al. 2004). Android dan website merupakan salah satu media edukasi gizi berbasis teknologi edutaintment yang sudah banyak diterapkan di luar negeri dan berpotensi untuk diterapkan di Indonesia. Indonesia merupakan negara yang penggunaan internetnya berkembang pesat. Sebanyak $85 \%$ dari total pengguna internet di Indonesia mengakses internet dengan menggunakan mobile phone sisanya menggunakan laptop dan PC (APJII \& PusKaKom UI 2014). Sebanyak 98\% anak-anak di Asia Tenggara telah menggunakan smartphone dan secara keseluruhan digunakan untuk bermain game, menonton video, dan penggunaan education apps (the Asianparent Insights 2014). Oleh karena itu, android dan website sangatlah efektif jika digunakan dalam edukasi gizi sehingga dapat memberikan dampak positif dari penggunaan smartphone dan internet pada anak SD.

\section{METODE}

\section{Desain, tempat, dan waktu}

Desain penelitian yang digunakan adalah quasy experimental. Penelitian dilaksanakan pada bulan Februari hingga Mei 2017 di 4 SD di Kecamatan Tuban, Provinsi Jawa Timur yang ditentukan secara purposif (SDN Kebonsari II, SDN Latsari, SDN Kutorejo I, dan SDN Mondokan).

\section{Jumlah dan cara penentuan subjek}

Populasi dalam penelitian ini adalah seluruh siswa kelas $5 \mathrm{SD}$ laki-laki dan perempuan. Penentuan jumlah contoh minimal untuk masingmasing kelompok dihitung menggunakan rumus (WHO 1996):

$$
\left.\mathrm{n} \geq\left\{\left(2 \times \mathrm{s}^{2} \times(\mathrm{Z} \beta+\mathrm{Z} \alpha)^{2}\right) / \mathrm{d}^{2}\right)\right\}
$$

Jumlah contoh minimal 36 siswa untuk setiap kelompok (kemungkinan drop out 15\%). Penentuan kelompok perlakuan dilakukan secara acak, yaitu perlakuan A (powerpoint presentation), perlakuan B (android), perlakuan C (website), dan perlakuan D (android \& website). Selain media tersebut, semua kelompok perlakuan mendapatkan alat bantu media edukasi gizi berupa poster. Penelitian ini telah mendapatkan Persetujuan Etik dari Komite Etik Penelitian Kesehatan Fakultas Kedokteran Universitas Indonesia No: 193/UN2.F1/ETIK/II/2017.

\section{Tahapan penelitian}

Proses pembuatan media. Pengembangan media edukasi gizi untuk anak sekolah dasar harus memerhatikan beberapa kriteria seperti isi materi, ukuran tulisan, gambar, dan warna sehingga akan meningkatkan tingkat kesukaan dan daya terimanya. Jenis media edukasi gizi yang dipilih adalah android dan website. Langkah pembuatan media edukasi gizi diawali dari pemilihan tema, proses pengembangannya, hingga media siap digunakan untuk intervensi. Tema yang dipilih yaitu gizi seimbang dan nama aplikasinya adalah "EDGIAS (Edukasi Gizi Anak Sekolah)". Isi materinya meliputi sepuluh Pesan Gizi Seimbang dalam Pedoman Gizi Seimbang yang dike- 
mas dalam bentuk tulisan, foto, gambar animasi, info grafis, dan video yang menarik. Pemilihan warna dan template disesuaikan dengan karakteristik anak (colorful).

Media android dan website dibuat menggunakan Wix.com: Free Website Builder, sebuah website builder gratis yang menyediakan berbagai macam template dan desain yang inovatif dan menarik. Langkah yang dilakukan untuk mengembangkan android dan website ini yaitu, memilih template yang tersedia di situs wix.com kemudian peneliti memasukkan logo, gambar, foto, tulisan, dan video yang sesuai. Langkah selanjutnya adalah penyesuaian tata letak, ukuran font tulisan, gambar, foto, dan video. Setelah website selesai, tinggal di publish untuk dapat diakses oleh siswa. Selain dapat ditampilkan dalam bentuk website, wix.com juga dapat menyajikannya dalam bentuk android yang dapat diakses dari smartphone (mobile view).

Strategi intervensi. Intervensi edukasi gizi diberikan pada ke-4 kelompok perlakuan (kontrol, android, website, android \& website). Materi yang diberikan meliputi 10 pesan dalam Pesan Gizi Seimbang dan diberikan sebanyak satu kali selama 5 hari yang dilakukan oleh peneliti dan rekan peneliti dengan menggunakan metode tatap muka, ceramah, dan praktik langsung (45-60 menit) serta diskusi (15-25 menit). Sebelum intervensi dilakukan, siswa menyiapkan smartphone dan laptop terlebih dahulu, kemudian peneliti menjelaskan dan mengarahkan siswa untuk mengakses situs edukasi gizi, selanjutnya siswa bebas menjelajah media android dan website yang berisikan gambar, pesan, dan video gizi seimbang sesuai waktu yang disediakan. Tahapan pelaksanaan intervensi meliputi pengambilan data pre-test/baseline (sebelum intervensi), 1 hari kemudian dilakukan intervensi, 1 minggu kemudian dilakukan post-test 1 , dan 1 bulan setelahnya dilakukan post-test 2/endline.

\section{Jenis dan cara pengumpulan data}

Jenis data yang dikumpulkan berupa data primer dan data sekunder. Data primer meliputi karakteristik individu dan keluarga, penerimaan terhadap media (kemudahan dipahami, ukuran tulisan, gambar, warna, jumlah materi, dan tingkat kesukaan), serta pengetahuan, sikap, dan praktik tentang gizi seimbang. Data pengetahuan, sikap, dan praktik diukur 3 kali, yaitu sebelum intervensi (pre-test/baseline) setelah intervensi (post-test 1) dan 1 bulan setelah intervensi (post- test 2/endline). Data sekunder meliputi keadaan umum lokasi penelitian. Data dikumpulkan melalui wawancara dan pengisian kuesioner yang telah diuji validitas dan reliabilitasnya.

\section{Pengolahan dan analisis data}

Pengolahan data meliputi verifikasi, coding, entry, cleaning, dan analisis. Data diolah dan dianalisis secara statistik deskriptif dan inferensia menggunakan Microsoft Office 2016 dan SPSS 23.0. Variabel pengetahuan, sikap, dan praktik diolah dengan menjumlahkan skor dari masing-masing pertanyaan berdasarkan jawaban sesuai dibagi total skor dikali seratus. Kategori tingkat perilaku menggunakan kategori baik (skor $>80 \%$ ), sedang (skor $60-80 \%$ ), dan kurang (skor $<60 \%$ ) dari total skor. Uji statistik digunakan untuk mengetahui perbedaan variabel pengetahuan, sikap, dan praktik gizi seimbang antar kelompok perlakuan serta perubahannya sebelum dan setelah edukasi gizi. Signifikansi uji statistik $(\mathrm{p}<0,05)$ menggunakan uji Wilcoxon, Mann Whitney, dan Kruskal-Wallis.

\section{HASIL DAN PEMBAHASAN}

\section{Karakteristik siswa sekolah dasar}

Usia subjek penelitian berkisar antara 1012 tahun, dengan proporsi jenis kelamin yang relatif sama antar SD (Tabel 1). Uang jajan subjek berkisar antara $>$ Rp 3.000-Rp 5.000/hari de-

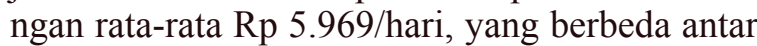
sekolah; siswa kelompok perlakuan A mempunyai uang jajan paling rendah. Terdapatnya perbedaan yang signifikan uang jajan subjek antar sekolah menunjukkan adanya perbedaan status sosial ekonomi orang tua subjek, yang ditunjukkan dari tingkat pendidikan dan pendapatan.

Lachat et al. (2009), menyebutkan bahwa salah satu yang memengaruhi besarnya uang jajan anak adalah pendapatan orang tua, semakin tinggi pendapatan orang tua maka akan semakin besar uang jajan anak. Tabel 1 juga menunjukkan hampir setengah dari jumlah subjek memiliki ayah yang berpendidikan SMA/sederajat, dan bekerja sebagai pegawai swasta/BUMN. Demikian pula hampir setengah dari total subjek memiliki ibu dengan pendidikan SMA/sederajat, dan sebagai ibu rumah tangga.

Tingkat pendidikan ayah dan ibu subjek kelompok perlakuan A paling rendah secara signifikan diantara kelompok yang lain, namun tingkat pendapatan orang tua tidak berbeda antar kelom- 


\section{Perdana dkk.}

pok perlakuan. Tingkat Pendidikan yang tinggi akan mempermudah seseorang untuk mendapatkan pengetahuan dan informasi yang berhubungan dengan makanan dan kesehatan (FernandezAlvira et al. 2012; Attorp et al. 2014).

Tingkat Pendidikan ibu akan memengaruhi kebiasaan makan dan pilihan makanan yang baik untuk anak, serta pengetahuan dan sikap yang baik tentang manfaat makanan sehat (Cribb et al. 2011; Yabanci et al. 2014). Lebih dari setengah subjek memiliki orang tua dengan tingkat pendapatan $<$ Rp 5.000.000/bulan dan lebih dari $90 \%$ keluarga subjek pada semua kelompok dikategorikan tidak miskin. Lebih dari setengah subjek memiliki jumlah keluarga yang kecil $(\leq 4$ orang).

Tabel 1. Sebaran subjek berdasarkan karakteristik individu dan keluarga

\begin{tabular}{|c|c|c|c|c|c|}
\hline Karakteristik subjek & $\begin{array}{c}\mathrm{A}(\mathrm{n}=36) \\
\mathrm{n}(\%)\end{array}$ & $\begin{array}{c}\mathrm{B}(\mathrm{n}=36) \\
\mathrm{n}(\%)\end{array}$ & $\begin{array}{c}\mathrm{C}(\mathrm{n}=36) \\
\mathrm{n}(\%)\end{array}$ & $\begin{array}{c}\mathrm{D}(\mathrm{n}=36) \\
\mathrm{n}(\%)\end{array}$ & $\mathrm{p}^{*}$ \\
\hline \multicolumn{6}{|l|}{ Jenis kelamin } \\
\hline Laki-laki & $18(50,0)$ & $21(58,3)$ & $17(47,2)$ & $16(44,4)$ & \multirow{2}{*}{0,469} \\
\hline Perempuan & $18(50,0)$ & $15(41,7)$ & $19(52,8)$ & $20(55,6)$ & \\
\hline \multicolumn{6}{|l|}{ Uang jajan (Rp 1.000/hari) } \\
\hline Rp 1-Rp 3 & $9(25,0)$ & $2(5,6)$ & $5(13,9)$ & $6(16,7)$ & \multirow{4}{*}{0,000} \\
\hline$>$ Rp 3-Rp 5 & $24(66,7)$ & $14(38,9)$ & $19(52,8)$ & $9(25,0)$ & \\
\hline$>\operatorname{Rp} 5$ & $3(8,3)$ & $20(55,6)$ & $12(33,3)$ & $21(58,3)$ & \\
\hline Rata-rata \pm SD & $4,4 \pm 1$ & $7,3 \pm 2,6$ & $5,8 \pm 2,4$ & $6,4 \pm 2,8$ & \\
\hline \multicolumn{6}{|l|}{ Pendidikan ayah } \\
\hline $\mathrm{SD} /$ sederajat & $7(19,4)$ & $1(2,8)$ & $0(0,0)$ & $1(2,8)$ & \multirow{4}{*}{0,000} \\
\hline $\mathrm{SMP} /$ sederajat & $5(13,9)$ & $0(0)$ & $4(11,1)$ & $2(5,6)$ & \\
\hline SMA/sederajat & $21(58,3)$ & $23(63,9)$ & $15(41,7)$ & $11(30,6)$ & \\
\hline PT (D3, S1, S2) & $3(8,4)$ & $12(33,3)$ & $17(47,2)$ & $22(61,1)$ & \\
\hline \multicolumn{6}{|l|}{ Pendidikan ibu } \\
\hline $\mathrm{SD} /$ sederajat & $4(11,2)$ & $1(2,8)$ & $1(2,8)$ & $3(8,3)$ & \multirow{4}{*}{0,009} \\
\hline $\mathrm{SMP} /$ sederajat & $12(33,3)$ & $1(2,8)$ & $3(8,3)$ & $2(5,6)$ & \\
\hline SMA/sederajat & $12(33,3)$ & $25(69,4)$ & $19(52,8)$ & $14(38,9)$ & \\
\hline PT (D3, S1, S2) & $8(22,2)$ & $9(25,0)$ & $13(36,1)$ & $17(47,2)$ & \\
\hline \multicolumn{6}{|l|}{ Pekerjaan ayah } \\
\hline PNS/ABRI/POLRI & $2(5,6)$ & $10(27,8)$ & $10(27,8)$ & $10(27,8)$ & \multirow{4}{*}{0,215} \\
\hline Pegawai swasta/BUMN & $23(63,9)$ & $15(41,6)$ & $14(38,9)$ & $15(41,7)$ & \\
\hline Wiraswasta & $6(16,7)$ & $10(27,8)$ & $11(30,6)$ & $11(30,6)$ & \\
\hline Buruh/petani & $5(13,9)$ & $1(2,8)$ & $1(2,8)$ & $0(0,0)$ & \\
\hline \multicolumn{6}{|l|}{ Pekerjaan ibu } \\
\hline PNS/ABRI/POLRI & $2(5,6)$ & $4(11,1)$ & $5(13,9)$ & $6(16,7)$ & \multirow{4}{*}{0,033} \\
\hline Pegawai swasta/BUMN & $5(13,9)$ & $4(11,1)$ & $4(11,1)$ & $6(16,7)$ & \\
\hline Wiraswasta & $7(19,4)$ & $2(5,6)$ & $15(41,7)$ & $5(13,9)$ & \\
\hline IRT & $22(61,1)$ & $25(69,4)$ & $12(33,3)$ & $19(52,8)$ & \\
\hline \multicolumn{6}{|l|}{ Besar keluarga (orang) } \\
\hline Kecil & $20(55,6)$ & $22(61,1)$ & $19(52,8)$ & $20(55,6)$ & \multirow{4}{*}{0,747} \\
\hline Sedang & $14(38,9)$ & $14(38,9)$ & $16(44,4)$ & $15(41,7)$ & \\
\hline Besar & $2(5,6)$ & $0(0,0)$ & $1(2,8)$ & $1(2,8)$ & \\
\hline Rata-rata \pm SD & $4,6 \pm 1,0$ & $4,3 \pm 0,8$ & $4,4 \pm 0,8$ & $4,4 \pm 1,0$ & \\
\hline \multicolumn{6}{|c|}{ Pendapatan orang tua (Rp 1 juta/bulan) } \\
\hline$<\operatorname{Rp} 5$ & $25(69,4)$ & $22(61,1)$ & $19(52,8)$ & $13(36,1)$ & \multirow{4}{*}{0,105} \\
\hline Rp 5-Rp 10 & $11(30,6)$ & $13(36,1)$ & $15(41,7)$ & $18(50,0)$ & \\
\hline$>\operatorname{Rp} 10$ & $0(0,0)$ & $1(2,8)$ & $2(5,6)$ & $5(13,9)$ & \\
\hline Rata-rata \pm SD & $3,6 \pm 2,2$ & $4,6 \pm 3,4$ & $5,1 \pm 3,0$ & $6,7 \pm 3,8$ & \\
\hline \multicolumn{6}{|c|}{ Pendapatan perkapita per bulan (Rp 1 000/kap/bulan) } \\
\hline Miskin & $6(16,7)$ & $3(8,3)$ & $3(8,3)$ & $0(0,0)$ & \multirow{3}{*}{0,244} \\
\hline Tidak miskin & $30(83,3)$ & $33(91,7)$ & $33(91,7)$ & $36(100,0)$ & \\
\hline Rata-rata \pm SD & $792 \pm 493$ & $1087 \pm 784$ & $1180 \pm 731$ & $1522 \pm 793$ & \\
\hline
\end{tabular}

Keterangan: $\mathrm{A}=$ Power point presentation, $\mathrm{B}=$ Android, $\mathrm{C}=$ Website, $\mathrm{D}=$ Android \& Website, ${ }^{*}$ hasil uji signifikan $(\mathrm{p}<0,05)$. 


\section{Tingkat penerimaan subjek terhadap media}

Penilaian subjek terhadap media edukasi android, dan website "Edgias (Edukasi Gizi Anak Sekolah)" mencakup 5 aspek, yaitu kemudahan dipahami, ukuran tulisan, gambar, warna, dan jumlah materi. Secara umum penilaian subjek terhadap media yang diberikan menunjukkan bahwa andoid lebih baik jika dibandingkan dengan website (Tabel 2).

Penilaian yang dilakukan terhadap tingkat kesukaan secara keseluruhan menunjukkan bahwa subjek sangat menyukai media android sedangkan website hanya cukup menyukai. Android merupakan media yang cukup mudah digunakan terutama pada anak-anak karena lebih menarik. Hal tersebut dapat dilihat dari mayoritas subjek menyakatakan bahwa aspek gambar dan warna pada media android sangat menarik. Selain itu, tulisan pada media android lebih dapat terbaca dengan baik. Subjek juga menganggap bahwa media android sangat mudah dipahami walaupun dari aspek jumlah materi sedikit lebih baik website dibanding android. Lieffers \& Hanning (2012) yang meneliti mengenai perbandingan penilaian status gizi menggunakan metode konvensional dengan aplikasi gizi untuk mobile devices menunjukkan bahwa secara keseluruhan, feedback positif dilaporkan untuk aplikasi ini. Aplikasi gizi untuk mobile devices memiliki potensi yang menarik jika digunakan dalam praktik dietetik. Aplikasi mobile berbasis android dapat memberikan informasi dengan cepat dan mudah karena dapat digunakan dimana saja dan dapat diakses kapan saja. Oleh karena itu, penggunaan aplikasi mobile berbasis android ini sangat efektif apabila digunakan untuk menyebarkan informasi gizi pada anak-anak.

Tabel 2. Sebaran subjek berdasarkan tingkat penerimaan terhadap media

\begin{tabular}{|c|c|c|}
\hline Variabel tingkat penerimaan & $\begin{array}{c}\mathrm{B}(\mathrm{n}=36) \\
\mathrm{n}(\%)\end{array}$ & $\begin{array}{c}\mathrm{C}(\mathrm{n}=36) \\
\mathrm{n}(\%)\end{array}$ \\
\hline \multicolumn{3}{|l|}{ Kemudahan dipahami } \\
\hline Sangat mudah dipahami & $22(61,1)$ & $10(27,8)$ \\
\hline Mudah dipahami & $13(36,1)$ & $21(58,3)$ \\
\hline Kurang mudah dipahami & $1(2,8)$ & $5(13,9)$ \\
\hline Sulit untuk dipahami & $0(0,0)$ & $0(0,0)$ \\
\hline \multicolumn{3}{|l|}{ Ukuran tulisan } \\
\hline Dapat terbaca dengan baik & $34(94,4)$ & $29(80,7)$ \\
\hline Terlalu besar & $0(0,0)$ & $3(8,3)$ \\
\hline Kurang dapat terbaca & $2(5,6)$ & $4(11,1)$ \\
\hline Tidak dapat dibaca & $0(0,0)$ & $0(0,0)$ \\
\hline \multicolumn{3}{|l|}{ Gambar } \\
\hline Sangat menarik & $23(63,9)$ & $21(58,3)$ \\
\hline Cukup menarik & $12(33,3)$ & $12(33,3)$ \\
\hline Kurang menarik & $1(2,8)$ & $3(8,3)$ \\
\hline Tidak menarik & $0(0,0)$ & $0(0,0)$ \\
\hline \multicolumn{3}{|l|}{ Warna } \\
\hline Sangat menarik & $19(52,8)$ & $16(44,4)$ \\
\hline Cukup menarik & $14(38,9)$ & $17(47,2)$ \\
\hline Kurang menarik & $3(8,3)$ & $2(5,7)$ \\
\hline Tidak menarik & $0(0,0)$ & $1(2,8)$ \\
\hline \multicolumn{3}{|l|}{ Jumlah materi } \\
\hline Cukup & $31(86,1)$ & $32(88,9)$ \\
\hline Terlalu banyak sekali & $4(11,1)$ & $4(11,1)$ \\
\hline Kurang banyak & $0(0,0)$ & $0(0,0)$ \\
\hline Kurang banyak sekali & $1(2,8)$ & $0(0,0)$ \\
\hline \multicolumn{3}{|l|}{ Tingkat kesukaan secara keseluruhan } \\
\hline Sangat menyukai $(>80)$ & $29(80,6)$ & $0(0,0)$ \\
\hline Cukup menyukai (>60-80) & $7(19,4)$ & $24(66,7)$ \\
\hline Kurang menyukai (40-60) & $0(0,0)$ & $12(33,3)$ \\
\hline Tidak menyukai $(<40)$ & $0(0,0)$ & $0(0,0)$ \\
\hline
\end{tabular}

Keterangan: $\mathrm{B}=$ Android dan $\mathrm{C}=$ Website. 
Perdana dkk.

\section{Pengaruh edukasi gizi terhadap perilaku gizi seimbang}

Pengetahuan tentang gizi seimbang. Pengetahuan gizi merupakan faktor penting yang memengaruhi perilaku gizi individu, keluarga, dan masyarakat (Demirozu et al. 2012). Praktik yang didasari oleh pengetahuan akan bertahan lama sehingga penting bagi anak untuk memeroleh pengetahuan gizi dari berbagai sumber seperti sekolah, media cetak, maupun media elektronik (Khomsan et al. 2009).

Secara umum pada semua kelompok, pengetahuan tentang gizi seimbang siswa SD saat pre-test/baseline cukup baik (skor rata-rata 8689) dan tidak berbeda antar perlakuan (Tabel 3). Namun masih ada siswa yang pengetahuannya berada dalam kategori sedang dan kurang, dan umumnya materi yang kurang dimengerti adalah tentang porsi makan. Setelah intervensi, terdapat peningkatan pengetahuan sebesar $1,5-3,9$ poin, yang berbeda signifikan antar kelompok. Pada kelompok android serta gabungan android \& website, peningkatan tersebut signifikan. Intervensi edukasi gizi meningkatkan pengetahuan gizi seimbang contoh. Peningkatan paling rendah pada kelompok kontrol, dan paling besar pada perlakuan android dan website. Kelompok perlakuan android dan website menunjukkan tingkat pengetahuan gizi yang lebih baik dibandingkan kelompok perlakuan lainnya. Suatu program yang komprehensif dapat berpengaruh penting terhadap pengetahuan gizi (Gibney et al. 2009). Android dan website merupakan media edutaintment yang komprehensif sehingga menjadi media yang efektif dalam edukasi gizi.
Pengukuran pengetahuan satu bulan setelah edukasi gizi (post-test 2/endline) menunjukkan adanya penurunan skor kecuali pada perlakuan android dan website, namun dibandingkan dengan skor saat pre-test/baseline, masih lebih tinggi. Penurunan yang paling banyak terjadi pada kelompok kontrol, bahkan lebih rendah dibandingkan baseline, dan termasuk kategori pengetahuan sedang. Hasil dari berbagai penelitian, intervensi edukasi gizi dapat meningkatkan perilaku anak SD dengan efektivitas yang berbeda-beda (Kocken et al. 2013; Nuryanto et al. 2014; Shariff et al. 2008; Shen et al. 2015; Wells et al. 2015).

Sikap tentang gizi seimbang. Sikap gizi merupakan kecenderungan seseorang untuk menyetujui atau tidak menyetujui terhadap suatu pernyataan yang diajukan terkait dengan pangan dan gizi (Khomsan et al. 2009). Edukasi gizi yang diberikan diharapkan dapat menumbuhkan sikap yang lebih baik terhadap gizi.

Tabel 4 menunjukkan sikap tentang gizi seimbang pada siswa SD secara umum pada semua kelompok perlakuan saat pre-test/baseline cukup baik (skor rata-rata 86-91), dan tidak berbeda antar perlakuan walaupun masih ada yang bersikap netral. Setelah intervensi edukasi gizi, terdapat peningkatan skor sikap sebesar 0,4-5,2 poin, yang berbeda secara signifikan antar kelompok. Intervensi edukasi gizi meningkatkan sikap gizi seimbang subjek, kecuali pada kelompok kontrol, yang skor sikapnya menurun. Peningkatan skor sikap paling besar pada kelompok android dan gabungan android \& website. Sikap terhadap makanan beragam menjadi lebih baik.

Tabel 3. Sebaran contoh berdasarkan pengetahuan tentang gizi seimbang

\begin{tabular}{|c|c|c|c|c|c|c|}
\hline Pengetahuan & Kategori & $\begin{array}{c}\mathrm{A}(\mathrm{n}=36) \\
\mathrm{n}(\%)\end{array}$ & $\begin{array}{c}\mathrm{B}(\mathrm{n}=36) \\
\mathrm{n}(\%)\end{array}$ & $\begin{array}{c}\mathrm{C}(\mathrm{n}=36) \\
\mathrm{n}(\%)\end{array}$ & $\begin{array}{c}\mathrm{D}(\mathrm{n}=36) \\
\mathrm{n}(\%)\end{array}$ & $\mathrm{p}^{*(\mathrm{a})}$ \\
\hline \multirow{4}{*}{$\begin{array}{c}\text { Pre-test } \\
\text { (Baseline) }\end{array}$} & Kurang & $1(2,8)$ & $1(2,8)$ & $0(0,0)$ & $1(2,8)$ & \multirow{4}{*}{0,232} \\
\hline & Sedang & $11(30,6)$ & $10(27,8)$ & $6(16,7)$ & $9(25,0)$ & \\
\hline & Baik & $24(66,6)$ & $25(69,4)$ & $30(83,3)$ & $26(72,2)$ & \\
\hline & Rata-rata skor & $86,0 \pm 0,1$ & $86,7 \pm 0,1$ & $88,5 \pm 0,1$ & $89,0 \pm 0,1$ & \\
\hline \multirow{3}{*}{ Post-test 1} & Kurang & $2(5,6)$ & $0(0,0)$ & $0(0,0)$ & $2(5,6)$ & \multirow{3}{*}{0,000} \\
\hline & Sedang & $6(16,7)$ & $6(16,7)$ & $3(8,3)$ & $3(8,3)$ & \\
\hline & $\begin{array}{l}\text { Baik } \\
\text { Rata-rata skor }\end{array}$ & $\begin{array}{l}28(83,3) \\
87,5 \pm 0,1\end{array}$ & $\begin{array}{l}30(83,3) \\
90,6 \pm 0,1\end{array}$ & $\begin{array}{l}33(91,7) \\
92,4 \pm 0,1\end{array}$ & $\begin{array}{l}31(86,1) \\
91,4 \pm 0,1\end{array}$ & \\
\hline \multirow{4}{*}{$\begin{array}{c}\text { Post-test } 2 \\
\text { (Endline) }\end{array}$} & Kurang & $9(25,0)$ & $2(5,6)$ & $0(0,0)$ & $1(2,8)$ & \multirow{4}{*}{0,314} \\
\hline & Sedang & $2(5,6)$ & $6(16,7)$ & $7(19,4)$ & $7(19,4)$ & \\
\hline & Baik & $25(69,4)$ & $28(77,8)$ & $29(80,6)$ & $29(80,6)$ & \\
\hline & Rata-rata skor & $78,3 \pm 24,1$ & $88,9 \pm 13,6$ & $90,6 \pm 9,2$ & $92,6 \pm 9,1$ & \\
\hline \multicolumn{2}{|c|}{ Delta-1 (Post-test 1-Baseline) } & 1,5 & 3,9 & 3,9 & 2,4 & \\
\hline \multicolumn{2}{|l|}{$\mathrm{p}^{*(\mathrm{~b})}$} & 0,058 & 1,000 & 0,021 & 0,001 & \\
\hline \multicolumn{2}{|c|}{ Delta-2 (Endline-Baseline) } & $-7,7$ & 2,2 & 2,1 & 3,6 & \\
\hline \multicolumn{2}{|l|}{$\mathrm{p}^{*(\mathrm{~b})}$} & 0,376 & 0,000 & 0,000 & 0,003 & \\
\hline
\end{tabular}

Keterangan: $\mathrm{A}=$ Kontrol, $\mathrm{B}=$ Android, $\mathrm{C}=$ Website, $\mathrm{D}=$ Android \& Website, ${ }^{\mathrm{a} h a s i l ~ u j i ~ K r u s k a l-W a l l i s, ~}{ }^{b}$ hasil uji Wilcoxon berdasarkan perubahan skor baseline \& endline. 
Tabel 4. Sebaran contoh berdasarkan sikap tentang gizi seimbang

\begin{tabular}{|c|c|c|c|c|c|c|}
\hline Sikap & Kategori & $\begin{array}{c}\mathrm{A}(\mathrm{n}=36) \\
\mathrm{n}(\%)\end{array}$ & $\begin{array}{c}\mathrm{B}(\mathrm{n}=36) \\
\mathrm{n}(\%)\end{array}$ & $\begin{array}{c}\mathrm{C}(\mathrm{n}=36) \\
\mathrm{n}(\%)\end{array}$ & $\begin{array}{c}\mathrm{D}(\mathrm{n}=36) \\
\mathrm{n}(\%)\end{array}$ & $\mathrm{p}^{*(\mathrm{a})}$ \\
\hline \multirow{4}{*}{$\begin{array}{l}\text { Pre-test } \\
\text { (Baseline) }\end{array}$} & Negatif & $0(0,0)$ & $0(0,0)$ & $0(0,0)$ & $0(0,0)$ & \multirow{4}{*}{0,331} \\
\hline & Netral & $7(19,4)$ & $11(30,6)$ & $10(27,8)$ & $3(8,3)$ & \\
\hline & Positif & $29(80,6)$ & $25(69,4)$ & $26(72,2)$ & $33(91,7)$ & \\
\hline & Rata-rata skor & $86,6 \pm 0,1$ & $86,9 \pm 0,1$ & $87,8 \pm 0,1$ & $91,3 \pm 0,1$ & \\
\hline \multirow{4}{*}{ Post-test 1} & Negatif & $2(5,6)$ & $0(0,0)$ & $0(0,0)$ & $0(0,0)$ & \multirow{4}{*}{0,009} \\
\hline & Netral & $4(11,1)$ & $5(13,9)$ & $10(27,8)$ & $2(5,6)$ & \\
\hline & Positif & $30(83,3)$ & $31(86,1)$ & $26(72,2)$ & $34(94,4)$ & \\
\hline & Rata-rata skor & $85,7 \pm 0,1$ & $92,1 \pm 0,1$ & $88,2 \pm 0,1$ & $94,5 \pm 0,1$ & \\
\hline \multirow{4}{*}{$\begin{array}{c}\text { Post-test } 2 \\
\text { (Endline) }\end{array}$} & Negatif & $4(11,1)$ & $1(2,8)$ & $1(2,8)$ & $1(2,8)$ & \multirow{4}{*}{0,121} \\
\hline & Netral & $7(19,4)$ & $6(16,7)$ & $9(25,0)$ & $3(8,3)$ & \\
\hline & Positif & $25(69,4)$ & $29(80,6)$ & $26(72,2)$ & $32(88,9)$ & \\
\hline & Rata-rata skor & $85,3 \pm 15,4$ & $88,6 \pm 13,1$ & $86,9 \pm 11,8$ & $93,8 \pm 7,5$ & \\
\hline \multicolumn{2}{|c|}{ Delta-1 (Post-test 1-Baseline) } & $-0,9$ & 5,2 & 0,4 & 3,2 & \\
\hline \multicolumn{2}{|c|}{$\mathrm{p}^{*(\mathrm{~b})}$} & 0,096 & 0,000 & 0,774 & 0,000 & \\
\hline \multicolumn{2}{|c|}{ Delta-2 (Endline -Baseline) } & $-1,3$ & $-1,7$ & $-0,9$ & 2,5 & \\
\hline \multicolumn{2}{|c|}{$\mathrm{p}^{*(\mathrm{~b})}$} & 0,500 & 0,289 & 0,726 & 0,031 & \\
\hline
\end{tabular}

Hal ini menunjukkan bahwa intervensi edukasi gizi memberikan pengaruh positif pada sikap subjek. Hasil penelitian ini sejalan dengan penelitian Sharrif et al. (2008) yang menunjukkan bahwa terdapat perbedaan yang signifikan pada skor sikap gizi pada kelompok yang diberikan intervensi edukasi gizi. Media perlakuan juga sangat memengaruhi, kelompok perlakuan android dan gabungan android \& website menunjukkan tingkat sikap gizi yang lebih baik jika dibandingkan dengan kelompok perlakuan lainnya.
Praktik tentang gizi seimbang. Praktik adalah respon seseorang terhadap suatu rangsangan. Setelah seseorang mengetahui stimulus atau objek, kemudian mengadakan penilaian atau pendapat terhadap apa yang diketahui, proses selanjutnya diharapkan ia akan melaksanakan apa yang diketahui atau disikapinya (Notoatmodjo 2007).

Semua kelompok perlakuan secara umum menunjukkan bahwa praktik gizi seimbang pada saat pre-test/baseline cukup baik (skor rata-rata

Tabel 5. Sebaran contoh berdasarkan praktik tentang gizi seimbang

\begin{tabular}{|c|c|c|c|c|c|c|}
\hline Praktik & Kategori & $\begin{array}{c}\mathrm{A}(\mathrm{n}=36) \\
\mathrm{n}(\%)\end{array}$ & $\begin{array}{c}\mathrm{B}(\mathrm{n}=36) \\
\mathrm{n}(\%)\end{array}$ & $\begin{array}{c}C(n=36) \\
n(\%)\end{array}$ & $\begin{array}{c}\mathrm{D}(\mathrm{n}=36) \\
\mathrm{n}(\%)\end{array}$ & $\mathrm{p}^{*(\mathrm{a})}$ \\
\hline Pre-test & Kurang & $0(0,0)$ & $1(2,8)$ & $0(0,0)$ & $0(0,0)$ & \multirow{4}{*}{0,157} \\
\hline \multirow[t]{3}{*}{ (Baseline) } & Sedang & $17(47,2)$ & $15(41,7)$ & $23(63,9)$ & $9(25,0)$ & \\
\hline & Baik & $19(52,8)$ & $20(55,6)$ & $13(36,1)$ & $27(75,0)$ & \\
\hline & Rata-rata skor & $81,9 \pm 6,5$ & $81,3 \pm 8,2$ & $80,8 \pm 6,1$ & $86,3 \pm 7,0$ & \\
\hline \multirow[t]{4}{*}{ Post-test 1} & Kurang & $2(5,6)$ & $2(5,6)$ & $2(5,6)$ & $2(5,6)$ & \multirow{4}{*}{0,893} \\
\hline & Sedang & $11(30,5)$ & $9(25,0)$ & $12(33,3)$ & $5(13,9)$ & \\
\hline & Baik & $23(63,9)$ & $25(69,4)$ & $22(61,1)$ & $29(80,5)$ & \\
\hline & Rata-rata skor & $87,5 \pm 0,1$ & $90,6 \pm 0,1$ & $92,4 \pm 0,1$ & $91,4 \pm 0,1$ & \\
\hline \multirow{4}{*}{$\begin{array}{l}\text { Post-test } 2 \\
\text { (Endline) }\end{array}$} & Kurang & $0(0,0)$ & $0(0,0)$ & $0(0,0)$ & $0(0,0)$ & \multirow{4}{*}{0,176} \\
\hline & Sedang & $8(22,2)$ & $9(25,0)$ & $14(38,9)$ & $9(25)$ & \\
\hline & Baik & $28(77,8)$ & $27(75,0)$ & $22(61,1)$ & $27(75)$ & \\
\hline & Rata-rata skor & $85,3 \pm 15,4$ & $88,6 \pm 13,1$ & $86,9 \pm 11,8$ & $86,8 \pm 7,9$ & \\
\hline \multicolumn{2}{|c|}{ Delta-1 (Post-test 1-Baseline) } & 5,6 & 9,3 & 11,6 & 5,1 & \\
\hline \multicolumn{2}{|l|}{$\mathrm{p}^{*(\mathrm{~b})}$} & 0,081 & 0,139 & 0,030 & 0,314 & \\
\hline \multirow{2}{*}{\multicolumn{2}{|c|}{$\begin{array}{l}\text { Delta-2 (Endline-Baseline) } \\
\mathrm{n}^{*(\mathrm{~b})}\end{array}$}} & 3,4 & 7,3 & 6,1 & 0,5 & \\
\hline & & 0,020 & 0,000 & 0,030 & 0,272 & \\
\hline
\end{tabular}

Keterangan: A= Kontrol, $\mathrm{B}=$ Android, $\mathrm{C}=$ Website, $\mathrm{D}=$ Android \& Website, ${ }^{2}$ hasil uji Kruskal-Wallis, 'basil uji Wilcoxon berdasarkan perubahan skor baseline \& endline. 
80-86) dan tidak berbeda antar perlakuan (Tabel 5). Namun masih cukup banyak (25-63,9\%) siswa yang praktiknya berada dalam kategori sedang dan kurang; umumnya siswa sering membeli jajanan yang kurang sehat dan mengonsumsi makanan instan. Intervensi edukasi gizi meningkatkan praktik gizi seimbang subjek. Setelah intervensi, terdapat peningkatan skor praktik sebesar 5,1 poin (kelompok gabungan android \& website) sampai 11,6 poin (kelompok website), yang berbeda secara signifikan antar kelompok. Praktik yang lebih banyak diterapkan antara lain kebiasaan minum air putih dan kebiasaan berdoa sebelum makan.

Pengukuran praktik satu bulan setelah edukasi gizi (post-test 2/endline) menunjukkan masih terdapatnya peningkatan skor pada semua kelompok perlakuan, walaupun terjadi penurunan dibandingkan post-test 2. Harari et al. (2013) menyatakan bahwa intervensi pendidikan gizi secara signifikan meningkatkan pengetahuan dan kebiasaan makan yang sehat. Penelitian Choi et al. (2008) menyatakan bahwa kebiasaan makan berhubungan signifikan dengan tingkat pengetahuan orang tua, pengetahuan gizi, dan sikap gizi anak. Pendidikan dan intervensi gizi telah diketahui menjadi cara yang efektif dalam mempromosikan perilaku makan dan gaya hidup yang sehat pada anak (Perez-Rodrigo \& Aracenta 2003). Selain itu, partisipasi aktif dari orang tua, serta peran guru, dan pihak sekolah dalam membuat kebijakan di sekolah akan berpengaruh dalam perubahan perilaku konsumsi pangan anak (Panunzio et al. 2007; Raiha et al. 2012).

\section{KESIMPULAN}

Media edukasi gizi berbasis android dan website dengan tema gizi seimbang telah berhasil dikembangkan dengan menunjukkan tingkat penerimaan dan kesukaan yang baik. Media edukasi gizi berbasis android menunjukkan hasil yang lebih baik jika dibandingkan dengan website dan media lainnya. Terdapat perubahan positif terhadap pengetahuan, sikap, dan praktik anak SD setelah edukasi gizi.

Sebelum intervensi, anak sekolah memiliki pengetahuan yang baik, sikap positif, dan praktik gizi seimbang yang baik berturut-turut sebesar 72,9\%, 78,5\%, 54,9\%. Setelah intervensi, pengetahuan, sikap, dan praktik meningkat sebesar $11,8 \%, 5,5 \%, 15,9 \%$. Kelompok perlakuan android dan website menunjukkan tingkat penge- tahuan gizi yang lebih baik dibandingkan kelompok perlakuan lainnya. Peningkatan skor sikap paling besar pada kelompok android dan gabungan android \& website. Terdapat peningkatan skor praktik pada kelompok gabungan android \& website dan kelompok website. Program edukasi gizi dapat memperbaiki perilaku gizi seimbang pada siswa sekolah dasar.

Pelaksanaan edukasi gizi berbasis android dan website sebaiknya dilakukan secara bertahap, berkelanjutan, dan terus menerus untuk mencapai perubahan perilaku yang positif dan mencegah penurunan perilaku pada sasaran sehingga dapat diterapkan secara berkelanjutan pada kehidupan sehari-hari anak. Program edukasi gizi ini kedepannya memerlukan keterlibatan dan dukungan dari berbagai pihak lainnya.

\section{UCAPAN TERIMA KASIH}

Peneliti mengucapkan terima kasih kepada pemberi dana penelitian, yaitu Ibu Hj. Ir. Sri Arjoeni Indarti

\section{DAFTAR PUSTAKA}

Attorp A, Scott JE, Yew AC, Rhodes RE, Barr SI, Jean NP. 2014. Associations between socio-economic, parental and home environment factors and fruit and vegetable consumption of children in grades five and six in British Columbia, Canada. BMC Pub Health 14:150-158.

[APJII] Asosiasi Penyedia Jasa Internet Indonesia dan [PusKaKom UI] Pusat Kajian Komunikasi Universitas Indonesia. 2014. Profil Pengguna Internet Indonesia. Jakarta: Asosiasi Penyedia Jasa Internet Indonesia.

Bergmann L, Clifford D, Wolff C. 2010. Edutaintment and Teen Modeling May Spark Interest in Nutrition \& Physical Activity in Elementary School Audiences. J Nutr Educ Behav 42:139-141.

Briawan D. 2016. Perubahan pengetahuan, sikap, dan praktik jajanan anak sekolah dasar peserta program edukasi pangan jajanan. J Gizi Pangan 11(3):201-210.

Brun J. 1985. Nutrition education: a model for effectiveness a synthesis of research. J Nutr Educ. 17: ii-S44.

Choi ES, Shin NR, Jung EI, Park HR, Lee HM, Song KH. 2008. A study on nutrition knowledge and dietary behavior of el- 
ementary school children in Seoul. Nutr Res Pract 2(4):308-316.

Cribb VL, Jones LR, Rogers IS, Ness AR, Emmett PM. 2011. Is maternal education level associated with diet in 10-year-old children?. Pub Health Nutr 14(11):2037-2048.

Demirozu BE, Pehlivan A, Camliguney AF. 2012. Nutrition knowledge and behaviours of children aged 8-12 who attend sport schools. Pro-Soc Behav Sci 46:4713-4717.

Fernandez-Alvira JM, Mouratidou T, Bammann K, Hebestreit A, Barba G, Sieri S, Reisch L, Eiben G, Hadjigeorgiou C, Kovacs E. 2012. Parental education and frequency of food consumption in European children: the IDEFICS study. Pub Health Nutr 16(3):487-498.

Gibney MJ, Margaretts BM, Kearney JM, Arab L. 2009. Gizi Kesehatan Masyarakat. Jakarta: EGC Pr.

Harari SH, Constantini S, Mann G, Lencovsky Z, Stark AH. 2013. Nutrition knowledge, attitude, and behaviors of Israeli female combat recruits participating in a nutrition education program. J Mil Med 178(5):517522.

Health DL, Panaretto KS. 2005. Nutrition status of primary school children in Townsville. Aus J Rural Health 13(5):282-289.

Ho M, Garnett SP, Baur L, et al. 2012. Effectiveness of lifestyle interventions in child obesity: systematic review with meta-analysis. Pediatrics 130:1647-1671.

Khomsan A, Faisal A, Riyadi H, Sukandar D, Mudjajanto S. 2009. Studi Peningkatan Pengetahuan Gizi dan Kader Posyandu serta Perbaikan Gizi. Bogor: Institut Pertanian Bogor.

Kocken PL, Van-Kesteren NMC, Buijs G, Snel J, Dusseldrop E. 2013. Students' beliefs and behaviour regarding low-calorie beverages, sweets or snacks: are they affected by lessons on healthy food and by changes to school vending machines?. Pub Health Nutr 18(9):1545-1553.

Lachat C, Khan LNB, Khan NC, Dung NQ, Anh NDV, Roberfroid D, Kolsteren P. 2009. Eating out of home in Vietnamese adolescents: socio-economic factors and dietary associations $^{1-4}$. Am J Clin Nutr 90:16481655.

Lieffers JRL, Hanning RM. 2012. Dietary assessment and self-monitoring with nutrition applications for mobile devices. Can J Diet Pract Res 73(3):253-260.
Notoatmodjo. 2007. Promosi kesehatan dan Ilmu Perilaku. Jakarta: Rineka Cipta.

Nuryanto, Pramono A, Puruhita N, Muis SF. 2014. Pengaruh pendidikan gizi terhadap pengetahuan dan sikap tentang gizi anak sekolah dasar. Jurnal Gizi Indonesia 3(1):32-36.

Panunzio MF, Antoniciello A, Pisano A, Dalton S. 2007. Nutrition education intervention by teachers may promote fruit and vegetable consumption in Italian students. Nutr Res. 27(9):524-528.

[Permenkes] Peraturan Menteri Kesehatan Republik Indonesia. 2014. Upaya Perbaikan Gizi. Jakarta: Kementerian Kesehatan RI.

Perez-Rodrigo C, Aranceta J. 2003. Nutrition education in schools: experiences and challenges. Eur J Clin Nutr 57(1):82-85.

Raiha T, Tossavainen K, Turunen H, Enkenberg J, Kiviniemi V. 2012. Effects of nutrition health intervention on pupils' nutrition knowledge and eating habits. Scan J Educ Res 56(3):277-294.

Rosario R, Araujo A, Oliviera B, Padrao P, Lopes $O$, Teixeira V, Moreira A, Barros R, Pereira B, Moreira P. 2013. Impact of an intervention through teachers to prevent consumption of low nutrition, energy-dense foods and beverages: a randomized trial. Prev Med 57: 20-25.

Shariff ZM, Bukhari SS, Othman N, Hashim N, Ismail M, Jamil Z, Kasim SM, Paim L, Samah BA, Hussein ZAM. 2008. Nutrition education intervention improves nutrition knowledge, attitude and practices of primary school children: a pilot study. Int Electron J Health Educ 11:119-132.

Shen M, Hu M, Sun Z. 2015. Assessment of school-based quasi-experimental nutrition and food safety health education for primary school students in two povertystricken countries of West China. PloS One 10(12): 0145090.

Singhal A, Cody M, Rogers E, Sabido M. 2004. Entertainment-Education and Social Change: History, Research, and Practice. Mahwah, New Jersey: Lawrence Erlbaum Associates Inc.

Suhardjo. 2003. Berbagai Cara Pendidikan Gizi. Jakarta: Bumi aksara.

The Asianparent Insights. 2014. Mobile Device Usage Among Young Kids 2014. A Southeast Asia Study (SEA): theAsianparent Insight. 
Perdana dkk.

Wells NM, Myers BM, Todd LE, Barale K, Gaolach B, Ferenz G, Aitken M, Henderson CR, Tse C, Pattison KO. 2015. The Effects of school gardens on children's science knowledge: a randomized controlled trial of low-income elementary schools. Int J Sci Educ 37(17):2858-2878.
[WHO] World Health Organization. 1996. Sample Size Determination Epidemiological and Statistical Metodhology Unit. WHO $(\mathrm{CH})$ : Geneva.

Yabanci N, Kisac I, Karakus SS. 2014. The effects of mother's nutritional knowledge on attitudes and behaviors of children about nutrition. Pro-Soc Behav Sci 116:44774481 . 